\title{
Epidemiology of care-related skin injuries: prevalence study in Colombia
}

Epidemiología de lesiones de piel relacionadas con el cuidado: estudio de la prevalencia en Colombia

Epidemiologia das lesóes da pele relacionadas com o cuidado: estudo de prevalência na Colômbia

Renata Virginia González Consuegra*; Wilmar José López Zuluaga**; Karen Tatiana Roa Lizcano***

\begin{abstract}
Background: It is important to identify care-related skin injuries (CRSIs) because they influence the quality of life, lead to high morbidity and mortality rates worldwide, and have high economic costs for healthcare systems.

Objective: To determine and characterize the prevalence of CRSIs in Colombia in 2016.

Methodology: Descriptive cross-sectional period prevalence study. The sample was obtained from 310 online surveys to Colombian nurses. A non-probability sampling of consecutive cases was used since all possible cases found during a given period were included.

Results: Data were obtained on the prevalence of CRSIs and metabolic etiology, as well as on the frequency of injuries according to gender, age group, healthcare service, prevention measures, use of topical products, and use of assessment scales.

Conclusion: Prevalence studies reveal the current situation with a view to influencing local and national institutional policies on quality care, patient safety, and public health.
\end{abstract}

Keywords: prevalence; injuries; nursing care

\section{Resumen}

Marco contextual: Identificar lesiones de piel relacionadas con el cuidado (LPRCs) es una estrategia importante, ya que inciden en la calidad de vida de las personas y representan una alta morbimortalidad a nivel mundial, sin contar los costos económicos generados al sistema de salud.

Objetivo: Establecer y caracterizar la prevalencia de LPRCs en Colombia en el año 2016.

Metodología: Estudio descriptivo transversal de prevalencia de periodo. Muestra obtenida de 310 encuestas online de enfermeras de Colombia. Se usó muestreo no probabilístico de casos consecutivos, ya que se tomaron todos los casos posibles encontrados durante un periodo determinado.

Resultados: Se obtuvieron datos de prevalencia para LPRCs y de etiología metabólica, así como la frecuencia de lesiones por género, grupos de edad, servicios de atención, medidas de prevención, uso de productos tópicos y uso de escalas de valoración.

Conclusión: La realización de estudios de prevalencia evidencian la situación actual con el fin de impactar en las políticas institucionales, locales y nacionales que abarcan la calidad de la atención, seguridad del paciente y salud pública.

Palabras clave: prevalencia; lesiones; atención de enfermería

*Ph.D., RN, Full Professor, National University of Colombia, 111101, Bogotá, Colombia [rvgonzalezc@unal.edu.co]. Contribution to the article: literature search, data collection, data analysis and discussion, article writing. Dirección para correspondência: Cra 45 \# 45-47 Int 4 , apt 203.

* RN, Nurse, National University of Colombia, 111101, Bogotá, Colombia [wilopezz@unal. edu.co. Contribution to the article: literature search, statistical analysis, data analysis and discussion, article writing. ***MSc., RN, National University of Colombia, 111101, Bogotá, Colombia [ktroal@unal.edu.
co]. Contribution to the article: literature search, data collection, discussion, article writing.

\section{Resumo}

Enquadramento: Identificar lesões cutâneas relacionadas com os cuidados (LPRCs) é uma estratégia importante, porque estas afetam a qualidade de vida das pessoas e representam uma alta morbidade e mortalidade em todo o mundo, sem contar os custos económicos gerados para o sistema de saúde.

Objetivo: Estabelecer e caracterizar a prevalência de LPRCs na Colômbia em 2016.

Metodologia: Estudo descritivo, transversal de prevalência de período. Amostra obtida a partir de 310 pesquisas online sobre enfermeiros da Colômbia. Foi utilizada amostragem não probabilística de casos consecutivos, já que todos os casos possíveis encontrados durante um determinado período foram realizados.

Resultados: Foram obtidos dados de prevalência para LPRCs e etiologia metabólica, bem como a frequência de lesóes por género, grupos etários, serviços de cuidados, medidas de prevenção, uso de produtos tópicos e uso de escalas de avaliação.

Conclusáo: Estudos de prevalência mostram a situação atual para impactar as políticas institucionais, locais e nacionais que abrangem a qualidade dos cuidados, a segurança do paciente e a saúde pública.

Palavras-chave: prevalência, lesões, cuidados de enfermagem

Received for publication: 15.05 .17

Accepted for publication: 10.10 .17

Série IV - n. ${ }^{\circ} 15$ - OUT./NOV./DEZ. 2017 


\section{Introduction}

According to the 2015 SIPIELA Colombia Declaration, care-related skin injuries (CRSI) are an important public health issue because of their negative impact on health and economy, as well as on patients and caregivers' physical, social, and psychological well-being. In addition, they are a source of high economic costs and increased workload for the health team.

CRSIs consist of skin alterations such as: pressure ulcer (PU), urinary, fecal, and dual incontinence-associated dermatitis (IAD), medical adhesive-related skin injury (MARSI), skin tear, among others. CRSIs are more common in very old or very young patients (elderly and infants) or in individuals who spend a significant amount of time hospitalized or confined to bed due to cognitive and/ or mobility impairment.

This study aimed to determine and characterize the prevalence of CRSIs in Colombia in 2016.

\section{Background}

PUs, which are called pressure injuries (PIs) by the National Pressure Ulcer Advisory Panel (NPUAP) since April 2016, have been documented since 1550 B.C., regardless of race, social distinction, and other factors. According to Torra-Bou et al. (2016), 98\% of PUs are preventable and associated with the disregard for patient safety and limited implementation of health system policies.

Moreover, PUs as CRSIs lead to deterioration in health and quality of life, as well as to economic impacts on health systems (Pancorbo Hidalgo, García Fernández, Torra I Bou, Verdú Soriano, \& Soldevilla-Ágreda, 2014).

The prevalence of PUs is generally used as an indicator of care quality, a concept with which the World Health Organization (WHO) agrees. In Colombia, the Ministry of Health and Social Protection created the Compulsory System of Health Care Quality Assurance (Sistema Obligatorio de Garantía de Calidad de la Atención en Salud, SOGCS) which is responsible for the patient safety pol- icy. According to the IBEAS study on patient safety in Latin-American hospitals, PUs are considered as adverse events.

According to Gray et al. (2007), IAD is an inflammation of the skin that occurs when urine or stool comes into contact with the perineal skin. It is classified as a clinical manifestation of moisture-associated skin damage, which is a health problem that has been undervalued due to lack of differentiation from PUs. It is also an issue associated with patient safety. The mortality rate is low among patients with IAD, but the morbidity rate is high (González Consuegra et al., 2016).

MARSI is a new category of skin damage which was defined by consensus. It is an understudied concept that requires further research on its prevalence and incidence, which would contribute to the development of strategies for reducing its occurrence (Yates, McNichol, Heinecke, \& Gray, 2017).

Skin tear is

A traumatic wound occurring principally on the extremities of older adults, as a result of friction alone or shearing and friction forces which separate the epidermis from the dermis (partial thickness wound) or which separate both the epidermis and dermis from the underlying structures (full thickness wound). (Payne \& Martin, 1993, p. 16)

Prevalence studies are highly used due to their methodological simplicity. They provide a picture of the problem at the time of its measurement and identify the proportion of affected people in a specific population, during a specific time period. It is necessary to analyze the epidemiology, etiology, and pathophysiology of CRSIs, which have increased in recent decades and require technological advances to enable appropriate prevention and management strategies (Domansky, 2012).

Therefore, this study aimed at identifying and characterize the prevalence of CRSIs in Colombia in 2016.

\section{Research question}

What is the prevalence of CRSIs in Colombia in 2016? 


\section{Methodology}

A descriptive cross-sectional period prevalence study was conducted with nurses working in healthcare institutions, at different levels of care, in Colombia. A total of 1,000 emails were sent inviting nurses to participate, and a total of 310 surveys were completed (one survey per patient) through the SurveyMonkey ${ }^{\circ}$ online platform, between October and December 2016. A non-probability sampling of consecutive cases was used since all possible cases found during the defined period were included.

The analysis included all completed surveys with data from Colombian institutions. After the exclusion of 33 incomplete surveys, the final analysis was performed using 277 surveys.

The following variables were considered: demographic data, namely age, gender, ethnicity, type of institution, and geographical location; type of institution, level of care, medical specialty of the service; characterization of the injury and prevention strategies, among others.

For data management purposes, the obtained data were inserted into a database without errors and inconsistencies. The analysis was then performed using the Epi Info ${ }^{\text {TM }}$ software, version 7.0. The prevalence was calculated by dividing the number of patients with CRSI by the num- ber of beds in all institutions, and multiplying it by 100 . The information was presented using descriptive statistics.

This study was classified as a risk-free study, where participants completed surveys on a voluntary basis and the confidential use of data for academic and scientific purposes was ensured. In addition, the name of the institutions where data were collected was kept anonymous.

\section{Results}

Data were obtained from 46 Colombian institutions: $81.23 \%$ were public healthcare institutions (Instituciones Prestadoras de Servicios de Salud, IPS), 83.75\% belonged to the subsidized health insurance regime, and $64.6 \%$ were specialized IPS (fourth level of care). Data were obtained from 11 departments, which cover 29\% of the national territory.

The data showed a population with CRSI with the following characteristics: $50.5 \%$ were women; $88.8 \%$ were mestizo; aged between 20 days and 96 years, with a mean age of 63.9 years. Most patients were older than 60 years $(67.1 \%)$. The most affected age groups were $60-65$ years (14.8\%), $70-74$ years (13.2\%), and $80-85$ years (10.4\%; Figure 1).

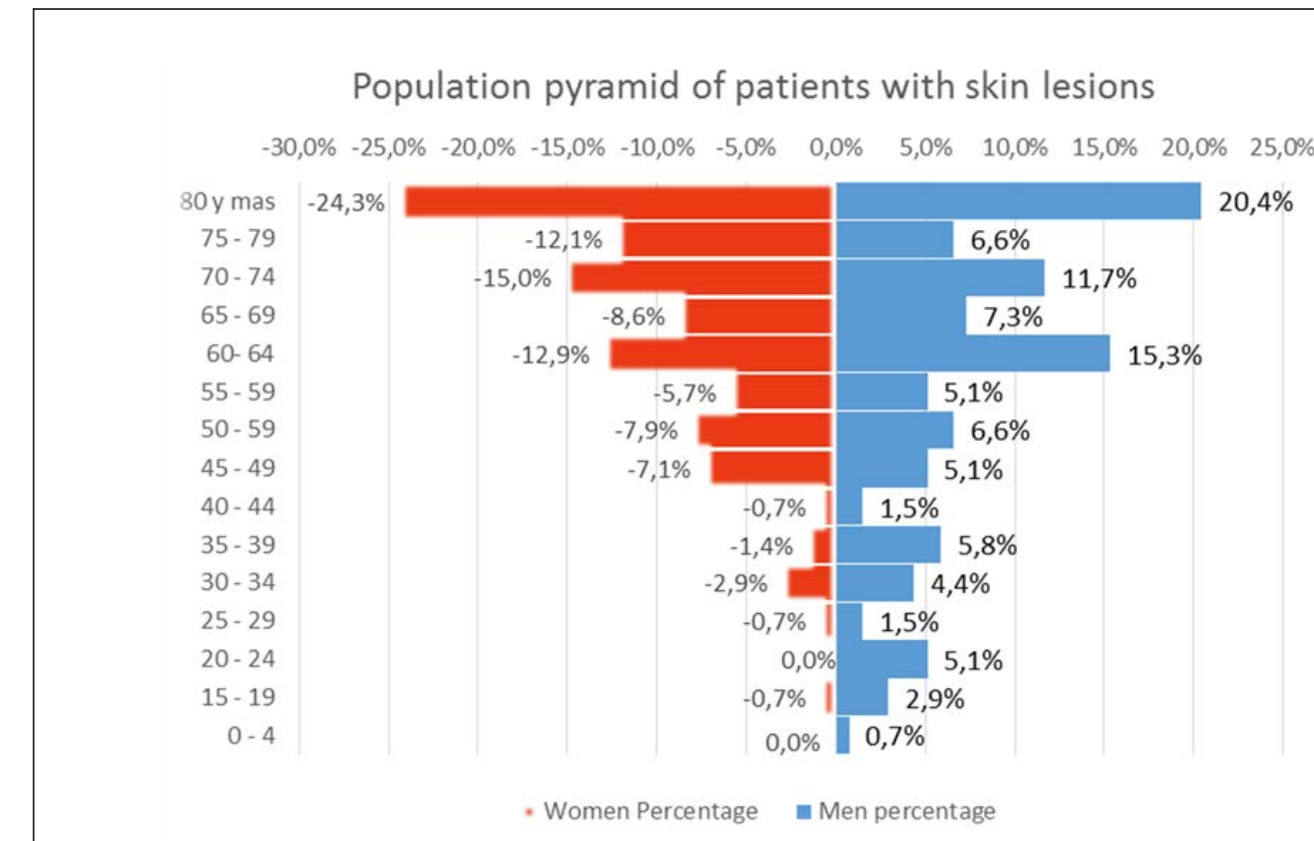

Figure 1. Population pyramid of patients with skin injuries. 
The total of skin injuries was 5.2, and includes CRSIs (69.7\%) and metabolic injuries $(30.3 \%)$, as follows: PU, 43.1\%; IAD, $10.2 \%$; MARSI $10.8 \%$, skin tear, $5.5 \%$; diabetic foot injury (DFI), 11.4\%; venous leg ulcer (VLU), 14.6\%; and arterial leg ulcer (ALU), 4.4\%.
Internal medicine (41.16\%) and surgery $(30.32 \%)$ were the units with a higher frequency of CRSIs (Figure 2). With regard to the origin of the CRSIs, $40.79 \%$ were acquired at the hospital, $37.55 \%$ at home, and $1.36 \%$ at the place of referral; $8.3 \%$ had an unknown origin.

\section{Frequency of skin lesions for attention services}

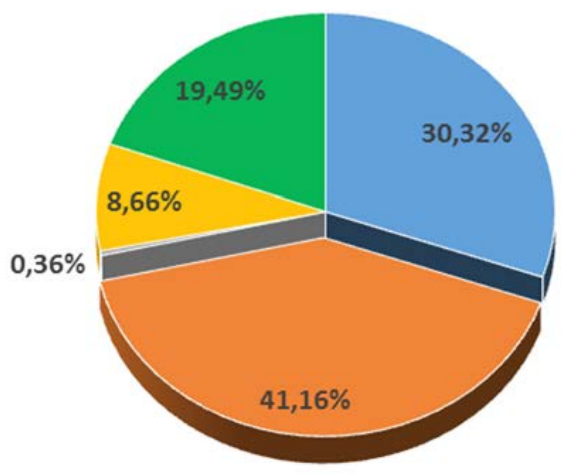

$$
\begin{aligned}
& \text { " Surgery } \\
& \text { - Internal Medicine } \\
& \text { " Oncology } \\
& \text { - ICU } \\
& \text { - Emergency }
\end{aligned}
$$

Figure 2. Frequency of skin injuries by care unit. Source: Authors.

Most PUs were located at the sacrum (42\%), IADs in the genitals $(56.8 \%)$, MARSIs $(66.7 \%)$ and skin tears $(36.8 \%)$ in the upper limbs; DFIs on the lateral margin $(82.1 \%)$; VLUs (46.4\%) and ALUs (29.41\%) around the malleoli. With regard to the number of simultaneous injuries, 19 patients had two injuries (PU plus IAD was the most common combination, with seven cases), eight patients had three injuries, and seven patients had four or more injuries.

The obtained data show that PUs are described in more detail and are more frequent $(53.4 \%)$. PUs were present in 148 patients: 109 had one injury, 24 had two injuries, 12 had three injuries, and three had four injuries. With regard to PU evolution, 38.3\% evolved between 1 and 15 days, $28.5 \%$ evolved between 1 and 6 months, and $27.4 \%$ evolved between 15 and 30 days.

Shear, pressure, and friction were most common etiologies involved in the onset of CRSIs $(49.8 \%)$.
As regards prevention measures, risk assessment scales (Escalas de Valoración de Riesgo, EVRUPP) were used in $15.9 \%$ of patients, with the Braden scale (50\%) and the Norton scale $(18 \%)$ being the most commonly used scales; no changes in position were made in $74.3 \%$ of patients; $24.3 \%$ of participants reported using topical skin care products including moisturizers, hyperoxygenated fatty acids (HFAs), and pressure relief pads, although $90.6 \%$ of respondents were not familiar with HFAs; $95.1 \%$ reported that the institution lacked special surfaces for managing pressure (SSMPs); and 3.8\% of participants reported that the institution faced legal actions due to CRSIs.

\section{Discussion}

This article focused on the characteristics of CRSIs in Colombia, considering that previous studies conducted in the country covered 
PUs and IAD (González Consuegra, Cardona Mazo, Murcia Trujillo, \& Matiz Vera, 2014), but did not include other injuries such as MARSIs, skin tears, DFIs, VLUs, and ALUs. These results are innovative because they report a total CRSI prevalence of 5.2\%, which includes PUs, MARSIs, skin tears, DFIs, VLUs, and ALUs. This information is not usually presented as a whole, both at national and international levels. The available literature addresses some injuries independently. In this study, the prevalence of PUs is $3.1 \%$, which is slightly higher than the prevalence of $2.21 \%$ found in the study of González Consuegra et al. (2014). This suggests that reporting have improved and that there is a greater awareness of the problem, which will allow for better care strategies. In a similar study conducted in a country with a more efficient health system, Pancorbo Hidalgo et al. (2014) found a prevalence of $18.9 \%$, which is much higher than the prevalence found in Colombia.

However, although the data obtained in Colombia show a slight improvement, underreporting is still a reality, which could point to health professionals' lack of interest or fear of possible reprisals as a result of the classification of PUs as adverse events that influence care quality indicators. Moreover, the data on reporting can be biased because prevalence was calculated using the total number of beds of the participating institutions, regardless of patients' health condition and PU risk (González Consuegra et al., 2014).

The nursing team is responsible for skin care and CRSI prevention strategies. Basic patient care involve addressing aspects related to the origin of these injuries, namely mobilization, venous access care, health devices care, hygiene care, skin care, and prevention of injuries, among other interventions (Barrera Arenas et al., 2016). Therefore, as reported by the participating nurses, $74.3 \%$ of them made no changes in position, $75.7 \%$ did not use topical skin care products, and $90.6 \%$ were not familiar with HFAs. However, given the multifactorial etiology of CRSIs and the fact that nurses are not solely responsible for it, the prevention of CRSIs entails various resources, such as bed linen, SSMPs, dressings for injury prevention, and mobilization devices, among others. The use of these resources requires institutional commitment and management involving feasible education programs with family engagement.

With regard to IAD, the prevalence is $0.5 \%$, which is lower than the one found in the study of Gray et al. (2007) with patients with fecal incontinence in nursing homes $(17 \%)$. In this study, the prevalence of injuries reached $50 \%$ in a population with $42 \%$ of incontinent adult inpatients. A previous Colombian study showed a prevalence of 5\% (González Consuegra, Mora Carvajal, Celis Moreno, \& David, 2015), which can suggest underreporting and/or ignorance regarding the identification of this type of injury in the Colombian context.

MARSI had a prevalence of $0.6 \%$, which is significantly low when compared to studies conducted in Australia (14 to 24\%; Domansky, 2012). This result can be associated with a lack of knowledge about the identification of MARSIs and the lack of importance assigned to their presence.

DFI had a prevalence of $2.2 \%$, which is low when compared to studies conducted in Brazil (9\%), Mexico (7.1\%), and Chile (6.7\%). VLU had a prevalence of $0.8 \%$. Domansky (2012) found a prevalence of active VLU in $1.48 \%$ people per 1,000 inhabitants. It is estimated that 2 to $3 \%$ of the world population has open VLU, which represents $70 \%$ of all ulcers (González Consuegra \& Gómez Ochoa, 2010). There is a lack of epidemiological information in Latin-America to allow the description and evaluation of the impact of the disease in each region, but that does not minimize its importance as a public health problem. The prevalence of ALU was $0.2 \%$. No studies were found in the literature that addressed this type of injury independently. Despite the progress in different science and technological fields, which has contributed to increasing life expectancy, the advance in the knowledge about aging-related diseases, cardiovascular diseases, and lifestyles is not taking place at the same rhythm as the increasing prevalence of these diseases (González Consuegra \& Verdú Soriano, 2010).

The frequency of skin injuries CRIs is higher in internal medicine and surgery units with $41.16 \%$ and $30.32 \%$, respectively. These results are similar to those reported in internal medicine units (41\%), orthopedics units $(8 \%)$, and intensive care, emergency, and home care units (7\%) (González Consuegra et al., 2014), as well as to those found in European studies with frequencies of $31 \%$ in palliative care, $57 \%$ in long-term care, $22 \%$ in rehabilitation care, and $81 \%$ in geriatrics (Ramos et al., 2013). These results are comparable because a large percentage of older patients with these injuries are often hospitalized in these units. The indexed literature has 
no comparable data concerning other injuries such as DAI, MARSI, skin tears, DFI, VLU, and ALU.

The most common anatomical site of the injury depends on the type of injury and is strictly related to its etiology. In the case of PUs, the most common location is the sacrum $(42 \%)$, which is line with the results found in European studies (30.7\%; Pancorbo Hidalgo et al., 2014) and in the study of prevalence conducted in Colombia (24\%). Due to the nature of the injury, IAD is usually located in the perineal region, whereas DFI, VLU, and ALU are usually located in the lower limbs. EVRUPPs were used in $15.9 \%$. It should be noted that, although participants report the use of the Norton and Braden scales, only the Braden scale has been used in validity tests in Colombian older people (Bernal, Curcio, Chacón, Gómez, \& Botero, 2001). Although there are several scales to assess CRSIs, they are not yet validated in Colombia. Moreover, studies do not mention the use of these scales, which is a limitation to the extent that the nursing team should use the CRSI risk assessment data to deliver health care according to the patient's condition (Barrera Arenas et al., 2016) or prevent the development of CRSIs. The information concerning the origin of the patients with CRSI coincides with the frequency of CRSI occurrence: $40.79 \%$ were inpatients, versus $54 \%$ in $2014 ; 37.55 \%$ were home care patients, versus $33 \%$ in 2014 ; and $13.36 \%$ were referred patients, versus $13 \%$ in 2014 (González Consuegra et al., 2014).

\section{Limitations}

Since there are no mechanisms to control reporting in Colombia, it is not possible to describe the size of the population. Despite the increase and improvement in data recording, underreporting still persists.

\section{Conclusion}

The results of this study are a valuable contribution for describing the prevalence of CRSIs in Colombia and allow designing a strategy for the identification, development, and implementation of measures to address the occurrence of CRSIs.

However, prevalence continues to be low when compared to other countries in the world, which indicates a persistent underreporting and lack of knowledge of the health- care team about prevention, assessment, diagnosis, treatment, and consequences for patients, professionals, institutions, and healthcare systems.

The results show that almost $70 \%$ of skin injuries are related to health care. These injuries could be prevented by a safe care delivery, which is possible by providing healthcare professionals with continuous and permanent prevention education programs. Furthermore, the education of patients and their families would help avoiding metabolic complications that are usually associated with chronic diseases and aging.

The prevention of CRSIs should be nurse-led, based on transparent clinical records, and free from punitive actions so that nurses can identify the problem and make decisions together with the interdisciplinary team involved in the health-disease process.

This study is a starting point for more analytical research studies that will allow comparing and establishing correlations between variables with the purpose of designing alternative care models capable of transforming nursing practice and the quality of care delivery.

\section{Acknowledgments}

The authors would like to thank nurses Yesika Tatiana Hernández Sandoval and Gustavo David Matiz Vera for their invaluable collaboration in the elaboration of the data collection survey, which was essential for conducting this research study.

\section{References}

Barrera Arenas, J. E., Pedraza Castañeda, M. C., Pérez Jiménez, G., Hernández Jiménez, P., Reyes Rodríguez, J. A., \& Padilla Zárate, M. P. (2016). Prevalencia de úlceras por presión en un hospital de tercer nivel, en México DF. Gerokomos, 27(4), 176-181. Retrieved from http:// scielo.isciii.es/scielo.php?script=sci_arttext\&pid=S1134-928X2016000400009

Bernal, M., Curcio, C., Chacón, J., Gómez, J., \& Botero, A. (2001). Validez y fiabilidad de la escala de Braden para predecir riesgo de úlceras por presión en ancianos. Revista Espanhola de Geriatria y Gerontologia, 36(5), 281-286. Retrieved from http://www.enfermeriaaps.com/portal/wp-content/ uploads/2015/07/Validez-y-fiabilidad-de-la-escala-de-Braden-para-predecir-riesgo.pdf

Domansky, R. C. (2012). Manual para la prevencao de lesoes de pele Recomendaciones basadas em evidencias. Rio de Janeiro, Brasil: Rubio. 
González Consuegra, R. V., \& Gómez Ochoa, A. M. (2010). Contexto social, biológico, psicológico, económico y cultural en personas con heridas en miembros inferiores. Avances En Enfermería, 26(1), 75-84.

González Consuegra, R. V., Cardona Mazo, D. M., Murcia Trujillo, P. A., \& Matiz Vera, G. D. (2014). Prevalencia de úlceras por presión en Colombia: Informe preliminar a preliminary report regarding pressure ulcer prevalence in Colombia. Revista Iberoamericana de Enfermería Comunitaria, 62(3), 12-15. doi:10.15446/revfacmed.v62n3.43004

González Consuegra, R. V., Mora Carvajal, L. H., Celis Moreno, J. S., \& David, M. V. G. (2015). Dermatitis asociada a incontinencia en adultos: Un problema sin definición, revisión sistemática. Revista de La Facultad de Medicina, 63(2), 199-208. doi:10.15446/revfacmed.v63n2.48349

González Consuegra, R. V., Matiz Vera, G. D., Guzmán Carrillo, L. X., Hernández Martínez, J. D., Mora Carvajal, L. H., \& Celis Moreno, J. S. (2016). Intervención y cuidado de enfermería a personas con lesiones de piel: Úlceras por presión y dermatitis asociada a incontinencia urinaria, fecal o mixta. Bogotá, Colombia: Universidad Nacional de Colombia.

González Consuegra, R. V., \& Verdú Soriano, J. (2010). Calidad de vida relacionada con heridas crónicas. Gerokomos, 21(3), 131-139. doi:10.4321/S1134928X2010000300007

Gray, M., Bliss, D. Z., Doughty, D. B., Ermer Seltun, J., Kennedy Evans, K. L., \& Palmer, M. H. (2007). Incontinence-associated dermatitis: A consensus.
Journal of Wound Ostomy \& Continence Nursing, 34(1), 45-54. Retrieved from http://journals.lww. com/jwocnonline/Fulltext/2007/01000/Incontinence_associated_Dermatitis_A_Consensus.8.aspx

Pancorbo Hidalgo, P. L., García Fernández, F. P., Torra I Bou, J. E., Verdú Soriano, J., \& Soldevilla-Ágreda, J. J. (2014). Epidemiología de las úlceras por presión en Espańa en 2013: 4. ${ }^{\circ}$ Estudio Nacional de Prevalencia. Gerokomos, 25(4), 162-170. doi:10.4321/ S1134-928X2014000400006

Payne, R. L., \& Martin, M. L. (1993). Defining and classifying skin tears: Need for a common language. Ostomy Wound Management, 39(5), 16-20, 22-24.

Ramos, A., Ribeiro, A. S. F., Almudena, M., Vázquez, M., Blanco, B., Corrales, J. M., ... Dones, M. (2013). Prevalencia de úlceras por presión en un centro sociosanitario de media-larga estancia. Gerokomos, 24(1), 36-40. doi:10.4321/S1134928X2013000100008

Torra-Bou, J. E., Verdú-Soriano, J., Sarabia-Lavin, R., Paras-Bravo, P., Soldevilla-Ágreda, J. J., \& García-Fernández, F. P. (2016). Las úlceras por presión como problema de seguridad del paciente. Gerokomos, 27(4), 161-167. Recuperado de http://scielo.isciii.es/scielo.php?script=sci_arttext\&pid=S1134-928X2016000400007

Yates, S., McNichol, L., Heinecke, S. B., \& Gray, M. (2017). Embracing the concept, defining the practice, and changing the outcome. Journal of Wound, Ostomy and Continence Nursing, 44(1), 13-17. doi:10.1097/WON.0000000000000290 
